\title{
Quality Assurance in Africa: Towards a Continental Higher Education and Research Space
}

\author{
Juma Shabani, Peter Okebukola, and Olusola Oyewole
}

\begin{abstract}
This article is a critical review of quality assurance in higher education in Africa with the purpose of identifying recent results, challenges still to be faced, and actions required to forcefully move towards the construction of an African higher education and research space (AHERS). The article identifies factors responsible for the decline in quality and proposes an integrated and holistic conceptual framework for analysing quality assurance. It reviews the various initiatives implemented in recent years and identifies, among the results, the establishment of new quality assurance agencies, the creation of a regional quality assurance system in East Africa, the strengthening of institutional development capacities, and capacity building in competencies-based curriculum reform. Challenges include the limited human capacity of quality assurance agencies, ineffectiveness in implementing harmonisation strategies, and the lack of tools required to compare qualifications. The article concludes with recommendations on promoting student and staff mobility to help realise the creation of AHERS.
\end{abstract}

Cet article est une critique de l'assurance qualité de l'enseignement supérieur en Afrique. Il a pour objectif d'identifier les récentes études,

About the authors: juma Shabani is Chargé de mission for Higher Education, United Nations Educational, Scientific, and Cultural Organization (UNESCO), Division of Teacher Development and Higher Education. Address queries to him at j.shabani@unesco.org. PETER oкebukola is President of the Global University Network for Innovation (GUNI)-Africa. Address queries to him at pokebukola@ yahoo.com. olusola oyewole is Vice Chancellor at the Federal University of Agriculture, Abeokuta, Nigeria. Address queries to him at oyewoleb@yahoo.com. ACKNOWLedgements: We are grateful to Professor M. Nkunya and Dr. J. Cosam for the information provided on the Inter-University Council for East Africa. 
les défis à relever, et les actions nécessaires pour provoquer la création d'un Espace Africain pour l'Enseignement Supérieur et la Recherche (AHERS). Cet article identifie les facteurs à l'origine du déclin de la qualité et propose un cadre théorique holistique complet pour analyser l'assurance qualité. Il critique les différentes initiatives mises en place ces dernières années et s'attarde plus spécifiquement sur la fondation de nouvelles agences chargées de l'assurance qualité, la création d'un système régional d'assurance qualité en Afrique de l'Est, le renforcement des capacités de développement des institutions, et le développement des capacités nécessaires pour établir une réforme des programmes axée sur les compétences. La capacité humaine limitée des agences d'assurance qualité, l'inefficacité quant à l'implémentation des stratégies d'harmonisation et le manque d'outils pour comparer les diplômes font partie des difficultés majeures. Nous terminons cet article en encourageant la mobilité des étudiants et des professeurs pour provoquer la création d'un Espace Africain pour l'Enseignement Supérieur et la Recherche.

\section{Introduction}

For various reasons, the quality of higher education in Africa has declined since the I980s. By the mid-I990s, the level of quality had fallen so low that all stakeholders in higher education, including institutions, governments, and donors agreed on the need and urgency of taking sustainable actions to reverse this trend and revitalize higher education. This situation has been used as a rationale for the organisation of the 1998 World Conference on Higher Education by UNESCO and its partners.

Several initiatives have followed to implement the recommendations of that 1998 conference. They include: (a) the revision of the conventions for mutual recognition of degrees and periods of studies, (b) harmonisation of higher education programmes and qualifications, (c) establishment of quality assurance agencies, (d) and capacity building in the fields of quality assurance and teaching and learning in higher education.

The 2009 World Conference on Higher Education held in Paris adopted recommendations to accommodate the new dynamics of higher education and research in the service of social progress and development. These recommendations include: (a) expanding access to higher education while ensuring quality, equity, and relevance, (b) establishing and/or strengthening quality assurance systems and higher education and research spaces, (c) and promoting regional and international mobility of students and academic staff.
This article critically reviews progress made in implementing recommendations made at the 2009 World Conference on Higher Education relating to the quality of higher education and quality assurance regimes in Africa, identifies challenges faced in achieving these recommendations, and proposes some actions that should be taken to move forcefully forward in constructing an African higher education and research space.

The article first recalls the factors responsible for the decline in quality of higher education since the I9 8 os, briefly presents factors related to the rapid increase in student enrolments in Francophone countries, and reviews the poor quality of students admitted to some universities.

It then presents a conceptual framework for analysing quality assurance in higher education in an integrated and holistic way. It also discusses the relationships between the world university rankings and the quality of African universities with the related question of the quality of research and knowledge production.

The third part reviews the major initiatives that have been launched in the areas of quality assurance mechanisms, harmonisation of degrees and periods of studies, and mobility at national, regional, and continental levels. The fourth part identifies and analyses challenges that confront ongoing efforts to improve the quality and strengthen quality assurance systems and their implications for constructing the African higher education and research space.

Finally, based on the conclusions and lessons drawn from these four analyses, the fifth section proposes actions that will be required to deal with the challenges confronting the construction of the African higher education and research space.

\section{The Quality of Higher Education in Africa}

Until the I980s, higher education institutions in Africa competed favorably with their counterparts in other parts of the world. Stakeholders now agree that several factors have contributed to the decline in quality of higher education in Africa. These include:

- A decline in per-unit costs

- A rapid increase in student enrolments

- The poor quality of students admitted to universities

- Poor standards of academic and research infrastructure, including libraries and laboratories

- Inadequate pedagogic training of academic staff

- Poor governance

- Limited capacity of quality assurance mechanisms

- The absence of quality assurance agencies to create and enforce 
mechanisms for ensuring quality.

- Frequent university closures mainly due to strikes (Materu, 2007; Shabani, 2013).

We illustrate the deterioration in the quality of higher education in Africa using two specific developments: (a) the rapid increase in student enrolments in Francophone countries, and (b) the poor quality of students admitted in some universities.

\section{Increased Enrolments in Francophone Countries}

A rapid increase in the number of students in a university will necessarily erode the minimum quality standards related to students and teaching and learning processes unless such increases are accompanied by planned and purposeful measures to prevent such deterioration. In the case of the African Francophone countries that have experienced rapid student enrolments, the compensatory quality assurances have not simultaneously become operational. The result is deleterious changes in:

- The maximum teacher/student ratio for the class

- The minimum space allotted for each student in the classroom

- The number of laboratories and workshops and minimum number of equipment and textbooks available for use by each student (e.g., microscope-to-student ratio, computer-to-student ratio; student-tobook-ratio)

- Acceptable teaching-learning practices

- High-quality classroom interactions

Higher education policies implemented in Francophone African countries since the turn of the 2Ist century have allowed universities to admit students who do not meet minimum standards of quality and to allocate a significant portion of their budgets to student social support, including scholarships, accommodation, catering, transport, and health coverage.

In Senegal, for example, in 2012 the number of students at the Cheikh Anta Diop University of Dakar, the country's main university, has multiplied threefold between 200 I and 20I2, growing from 24,776 to 75,240 students for a total carrying capacity of 23,253 students. This increase in enrolment has contributed to the deterioration of the student-to-teacher ratio, which stood in 2013 at one teacher per $47 \mathrm{stu}$ dents (UCAD, 20I3), against the ratio of 15.6 students per teacher in the Organisation for Economic Co-operation and Development member countries (OECD, 2013).

In 20I2, public universities in Senegal admitted $66 \%$ of new students and, according to the National Development Plan for Higher Education and Research for 20I3-20I7, this percentage will be maintained until 20I5, then decline slightly to $65 \%$ until 2018 (CNAES, 20I3a; PDESR, 20I3).
Further complicating the question of quality in Senegal's higher education is the budgeting priority. Currently, $70 \%$ of the universities' operating budget is allocated to student social support, leaving limited resources with which to maintain minimum quality standards. The planned rate at which new students will continue to be admitted in the coming years will further reduce universities' capacity to assure the quality of the higher education they are providing.

Another example of the decline in quality of higher education in Francophone countries is provided by Mali. In 2008, the University of Bamako had about 80,000 students but fewer than 700 full-time teachers, almost $70 \%$ of whom were assistant lecturers who lacked PhDs. Furthermore, the university did not even have a central library (University of Bamako, 2008). In 20I2, the number of students was so great that managing the university had become difficult. The government's decision was to split the University of Bamako into four autonomous universities, but this solution was only temporary, since the number of students is continuing to grow rapidly in each of the new universities. Indeed, by March 20I4, the total student enrolments in the four universities had reached 122,250 (Sangala, 2014).

The situation is different in Anglophone countries where universities more strictly require that applicants meet minimum quality standards, and competition for admission is high. In Nigeria, for example, in 2007 at Osun State University, over I00,000 candidates applied for 500 available spaces; and in 20II, a total of 99,I95 candidates applied to the University of Lagos. Only about 9,0०० could be offered admission (Okebukola, 20I4)

\section{Quality of Students Admitted to Universities}

In some African countries, the quality of higher education is negatively affected by the inadequate preparation and academic skills of new students who are admitted to universities. Indeed, implementing the "Education for All" goals has led to a massive increase in primary school pupils, an enrolment "bulge" that is now impacting lower secondary schools and, consequently, to a shortage of teachers in these levels of the education. Certainly, this "bulge" will soon be straining the resources of the upper half of a secondary school system.

Indeed, in Sub-Saharan Africa, a third of the countries suffer from a shortage of teachers in primary education. In lower secondary schools, Sub-Saharan Africa alone accounts for almost half of the global teacher shortage (UNESCO Institute for Statistics, 20I3). In addition to the teacher shortage, learning takes place in crowded classrooms, and some of the teachers do not master the subjects that they are expected to teach 
as well as pedagogic techniques required to handle such large classes.

In East Africa and Southern Africa, regions that implement monitoring of learning achievements programmes, some countries show low levels of learning achievements; and the deficiencies accumulated since primary education persist to the university level (Spaull, 20I3).

\section{A Quality Assurance Conceptual Framework}

\section{The Framework}

One of the major recommendations of the I99 8 World Conference on Higher Education, reaffirmed at the 2009 World Conference on Higher Education, was to "pursue the expansion of access to higher education while ensuring equity, relevance, and quality." That recommendation highlighted the importance of capacity-building in quality assurance, and teaching, and learning as relevant strategies that could contribute effectively to the revitalisation and further development of higher education in Africa. On the other hand, through the Action Plan for the Second Decade of Education for Africa, the African Union Commission committed in 2006 to promoting quality assurance and to developing a higher education harmonisation programme.

As part of the follow-up to the Second Decade of Education in Africa, Okebukola and Shabani (2007) proposed a conceptual framework for analysing quality assurance in higher education in a holistic way. The framework takes into account the components of a higher education system, especially those related to inputs, processes, and outputs. It stresses that, once these system elements are identified, minimum standards must be defined for each component. These minimum standards will be harmonised and used in the process of developing the continental frameworks.

As shown in Figure I, "Dimensions of Quality Assurance of Teaching and Learning in Higher Education," to assure the quality of teaching and learning, the input segment of the framework includes at least the students, teachers, non-teaching staff, managers, curriculum, facilities, finance, and instructional materials. Elements of the process segment cover teaching and learning processes, research, use of time and space, student services, community participation, and management. If these inputs and processes interact effectively, the output should include skilled and employable graduates who will also be responsible citizens, able to contribute to the economic and social development and the production of new knowledge.

For each element of the three segments (input, processes, and outputs), minimum standards must be defined. In an educational system, the minimum standard is the threshold value or benchmark
Figure 1. Dimensions of quality assurance of teaching and learning in higher education.

\begin{tabular}{|c|c|c|}
\hline INPUT & PROCESS & OUTPUT \\
\hline $\begin{array}{l}\text { - Students } \\
\text { - Teachers } \\
\text { - Non-teaching } \\
\text { staff } \\
\text { - Managers } \\
\text { - Curriculum } \\
\text { - Facilities } \\
\text { - Finance } \\
\text { - Instructional } \\
\text { materials } \\
\text { - Other resources }\end{array}$ & $\begin{array}{l}\text { - Teaching and } \\
\text { learning } \\
\text { processes } \\
\text { - Research } \\
\text { - Use of time and } \\
\text { space } \\
\text { - Student services } \\
\text { - Administration } \\
\text { - Leadership } \\
\text { - Community } \\
\text { participation } \\
\text { - Management }\end{array}$ & $\begin{array}{l}\text { - Skilled and } \\
\text { employable } \\
\text { graduates } \\
\text { - Responsible } \\
\text { citizens } \\
\text { - Economic and } \\
\text { social } \\
\text { development } \\
\text { - Production of } \\
\text { new knowledge }\end{array}$ \\
\hline
\end{tabular}

below which performance should not be deemed acceptable. Acceptable performance presents values above established minimums. The setting of minimum standards is important for a host of reasons. One of the most important is that such standards provide an objective measure for judging the performance of an education system. Second, they also provide an empirical basis for planning and budgeting. We ensure that minimum standards are attained through the quality assurance process (Okebukola, 20I3; Okebukola \& Shabani, 20I2).

Meeting the challenges of quality assurance at the continental level includes (a) promoting the mutual recognition of degrees and periods of studies, and (b) enhancing the intra-African mobility of staff and students. Such goals require harmonising the minimum standards of higher education systems at the national and regional levels. Quality assurance processes will aid in attaining minimum standards by helping to improve the quality of inputs and processes of the quality assurance framework, including the employment of information and communication technologies.

\section{World University Rankings and the Quality of African Universities}

The quality of higher education teaching, learning, and research in African universities is determined from the quality of the elements of inputs, processes, and outputs identified in Figures I and 2 and measured on the basis of preestablished minimum standards. While ranking systems are not a completely satisfactory way of measuring quality, such systems provide helpful comparisons of achievement and reputation.

To improve the quality of Nigerian universities, the National Universities Commission of Nigeria launched its ranking scheme in 200I, 
using only one indicator: the programme accreditation score based on the results of the I999-2000 national accreditation exercise. Since I99I this commission conducts regular accreditation evaluations of university programmes to determine whether they comply with preestablished minimum academic standards.

The objective of this initiative was to provide university stakeholders in Nigeria and beyond with relevant information that could help them to make informed decisions on matters related to the quality of universities. Students could use university rankings to help them choose a university with programmes that aligne with their aspirations. University leaders could use rankings to identify areas of weakness to help plan necessary corrective measures. Employers could recruit candidates with appropriate job profiles, and the government could identify universities that could be elevated to the status of "centre of excellence."

With the emergence in 2002 of the world university rankings, a controversial debate has continued on the relationship that should exist between the quality of African universities and their presence in the global league tables. (For a detailed description of the three major global ranking schemes-the Academic Ranking of World Universities, the Times Higher Education ranking, and Webometrics ranking-see Okebukola, 20IIa, and Mohamedbhai, 20I2a.) In the 20I2-20I3 rankings, only three African universities, all of them from South Africa were ranked in the Times Higher Education and Academic Ranking of World Universities league tables. These are the Universities of Cape Town, Witwatersrand, and KwaZulu Natal. Webometrics ranked only two African universities in the top 500 universities in the world: the University of Cape Town and Stellenbosch University.

We take the position that there is no direct relationship between these three global university ranking systems and the quality of African universities. The chief reason for this lack of relevance is that the profile of universities involved in the global rankings schemes is very specific and their criteria and indicators are not related to those used in assessing the quality of teaching, learning, and research in African universities. Indeed, according to Marope, Wells, and Hazelkorn (20I3, p. I4) rankings mainly focus on universities that "tend to be older $(200+$ years $)$ established institutions with 25,000 students or more, 2,500 faculty or more, and with endowments of over US\$ billion and annual budgets of more than US\$2 billion" (p. I4). Moreover, ranking schemes mainly measure universities' activities related to research outputs and, unlike quality assurance measures in African universities, do not give necessary attention to teaching, learning, and community services and to processes required to achieve the expected outputs.
Figure 2. Dimensions of quality assurance of research in higher education.

\begin{tabular}{|c|c|c|}
\hline INPUT & PROCESS & OUTPUT \\
\hline $\begin{array}{l}\text { - Doctoral } \\
\text { enrolments } \\
\text { - Permanent } \\
\text { academic staff } \\
\text { with PhDs } \\
\text { - Research } \\
\text { facilities } \\
\text { - Specialised } \\
\text { libraries }\end{array}$ & $\begin{array}{l}\text { - PhD supervision } \\
\text { and mentoring } \\
\text { - Research } \\
\text { capacity building } \\
\text { - Data collection } \\
\text { and analysis }\end{array}$ & $\begin{array}{l}\text { - Doctoral } \\
\text { graduates } \\
\text { - Research } \\
\text { articles } \\
\text { - Production } \\
\text { of new } \\
\text { knowledge }\end{array}$ \\
\hline
\end{tabular}

As this profile shows, such criteria and indicators do not accommodate the current reality of African universities. For example, the selection criteria used by the Academic Ranking of World Universities published by Shanghai Jiao Tong University in China mainly focuses on research. Its indicators include: (a) alumni and staff who win Nobel Prizes and Fields Medals; (b) highly cited researchers in 2I broad subject categories; (c) articles published in Nature and Science; and (d) articles indexed in Science Citation Index-Expanded (SCIE) and Social Science Citation Index (SSCI).

However, it is now agreed that criteria and indicators used in global rankings can be adapted appropriately to enhance the quality of African universities. By 2004, for example, Nigeria had expanded its initial single-criterion ranking scheme to accommodate the criteria and indicators of the major world ranking schemes. The resulting new national ranking scheme with I2 indicators is now widely used by stakeholders in Nigeria and beyond. According to the National Universities Commission of Nigeria, the government of Nigeria has already improved learning and research facilities in public universities by about 30\% since the national ranking was initiated in 200I (Okebukola, 20IIa).

\section{Quality of Research and Knowledge Production}

The quality assurance conceptual framework can also be used to analyse quality assurance of research. See Figure 2, "Dimensions of Quality Assurance of Research in Higher Education," for the inputs, processes and outputs of the system.

Minimum standards for research include the following: (a) the minimum score on research to be eligible for appointment or promotion; (b) the relevance of research to national socio-economic development, (c) the size of the research grant won through a competitive process; (d) the number of collaborative and inter-disciplinary research projects; (e) 
the minimum number of articles published in reputable international journals; and (f) the registered patents and inventions indexed in global databases within the last I2 calendar months (Okebukola, 20I3).

We agree that a country's ability to participate competitively in the knowledge economy society is related to the capacity of its universities in the production, reproduction, and dissemination of knowledge and its training of new generations of researchers who will continue the pursuit of knowledge production. Hence, there is a direct relationship between quality assurance of research and knowledge production.

In its National Development Plan: Vision 2030, South Africa has developed a set of indicators that should enable the government to achieve its higher education objectives, two of which are directly related to knowledge production: (a) increasing the number of $\mathrm{PhD}$ graduates per year from I,42I in 2010 to 5,000 in 2030, and (b) the number of academic staff with a PhD from $36 \%$ of the total number of academics in higher education in 2010 to $75 \%$ by 2030 .

Based on a detailed analysis of the growth rates of doctoral enrolments and graduates and academics with a PhD during I996-2010 and current trends in the development of higher education in South Africa, Mohamedbhai (20I2b) found that these targets unrealistic, especially since there is no evidence showing that they may be significantly improved.

\section{Quality Assurance Initiatives at the National Level}

During the last decade, several initiatives have been taken to improve the quality and quality assurance of higher education at the national, regional, and continental levels. These initiatives include the development of quality assurance agencies, the harmonisation of the higher education strategy and the construction of an African higher education and research space.

The first national quality assurance agency was established in I962 in Nigeria. By 20I2, 2I African countries had governmentally established quality assurance agencies, and a dozen other countries were at relatively advanced stages in achieving this goal. Only five Francophone countries in Sub-Saharan Africa have quality assurance agencies: Burundi, Cameroon, Mauritius, Senegal, and Rwanda. However, it should be noted that Francophone countries have reliable quality assurance mechanisms for the faculties of medicine implemented in collaboration with CAMES (Conseil Africain et Malgache pour l'Enseignement Supérieur; African and Malagasy Council for Higher Education). These are voluntary processes whereby external evaluation is conducted by experts provided by institutions and/ or regional and international networks. Indeed, in recent years, at least six faculties of medicine were evaluated with support from the International Conference of Deans and Faculties of Medicine of French-speaking countries (Conférence Internationale des Doyens et des Facultés de Médecine d'Expression Francaise; CIDMEF), a network of more than 130 medical schools in 40 countries. The World Health Organisation and the Conference of Rectors of Universities of West Africa and the Indian Ocean have also supported experts to conduct external evaluations of faculties of medicine in Francophone African countries. Quality assurance of faculties of medicine is one of CIDMEF's core programmes.

National quality assurance agencies were initially established to ensure the quality of programmes delivered by private institutions through the face-to-face mode. This mandate has gradually been expanded to include public institutions and other modes of delivery-in particular, online learning (Daniel \& Uvalic-Trumbic, 20I3; Shabani, 20I3).

Currently, the national quality assurance agencies perform the following functions:

- Assess institutions and/or programmes

- Approve higher education public and private institutions

- Approve new academic programmes and higher education institutions

- Establish minimum academic standards

- Carry out annual performance reviews

- Monitor and accredit institutions and programmes

In some countries, these functions are limited to private higher education institutions. In other countries such as Nigeria and Ghana, the functions of quality assurance agencies are much larger and include, for example, the coordination of external examiners and approval of foreign institutions. The National Universities Commission of Nigeria is the only quality assurance agency that conducts university rankings (Okebukola \& Shabani, 20I2).

The responsibilities assigned to quality assurance agencies are revised periodically to include the new challenges facing the quality of higher education. In Kenya, for example, in 2013 , the government established the Commission for University Education as a replacement for the Commission on Higher Education, which had acted as the national quality assurance agency since I985. The Commission for University Education has been entrusted with broader functions, including advising the government on university education policy.

The government has also created three new bodies that should contribute to the promotion of quality assurance in Kenya. These are: (a) 
the Universities Funding Board, to coordinate the financing of universities; (b) the Kenya Universities and Colleges Central Placement Service, to handle admissions to public universities and colleges; and (c) the Technical and Vocational Education Funding Board, to coordinate the funding of that sector (University Act, 20I2).

Several African countries are planning to expand the carrying capacity of their higher education systems to achieve the goal of increasing their higher education participation rate. Quality assurance agencies in countries where they exist will be challenged to undertake accreditation of the new programmes and institutions. It is also anticipated that countries without such agencies will be under pressure to establish them in order to ensure that the new institutions meet the minimum standards required to participate in mobility schemes at regional and continental levels. In both cases it will be necessary to strengthen the human and institutional capacities of the quality assurance agencies.

\section{Quality Assurance Initiatives at the Regional Level}

At least two regional organisations are actively involved in quality assurance in Africa. These are the African and Malagasy Council for Higher Education (CAMES) and the Inter-University Council for East Africa (IUCEA).

\section{The African and Malagasy Council for Higher Education (CAMES)}

The African and Malagasy Council for Higher Education (Conseil Africain et Malgache pour l'Enseignement Supérieur; CAMES) was established in 1968, with the main objective of harmonising and coordinating higher education policies and programmes in the I9 member countries. These countries are, in alphabetical order: Benin, Burkina Faso, Burundi, Cameroon, Central African Republic, Congo, Democratic Republic of Congo, Equatorial Guinea, Ivory Coast, Gabon, Guinea, Guinea Bissau, Madagascar, Mali, Niger, Rwanda, Chad, Senegal, and Togo.

Currently, CAMES implements three quality assurance programmes. These are the Licence-Master-Doctorate (LMD) reform; the programme on the mutual recognition of degrees, and the capacity-building programme in quality assurance.

1. The Licence-Master-Doctorate (LMD; also Bachelor/Master/Doctorate) Reform. This reform began in Europe in 1999 with the adoption of the Bologna Declaration, which launched the Bologna Process. This reform had the goal of making academic degree standards and quality assurance standards more comparable and compatible through- out Europe by 20I0. Its main priorities are: (a) the introduction of the three-stage degree system, (b) compatible measures of quality assurance, and (c) recognition of qualifications and periods of studies (European Ministers of Higher Education, 200I; 2003). In 2005 the heads of states of the Central African Economic and Monetary Community (Communauté Économique et Monétaire de l'Afrique Centrale; CEMAC) adopted a declaration affirming the establishment of a space for higher education, research, and vocational training that would include the implementation of the LMD reform (CEMAC, 2005). The six member countries are Cameroon, Central African Republic, Congo, Gabon, Equatorial Guinea, and Chad. The CAMES Council of Ministers adopted a resolution in 2006 on the transition to the LMD system in all its member states (CAMES, 2006). This resolution entrusted to CAMES academic bodies the responsibility of setting up, under the guidance of the CAMES secretary general, appropriate mechanisms for the supervision, monitoring, and evaluation of the proposed reform.

In 2007, the Council of Ministers of the West African Economic and Monetary Union (Union Économique et Monétaire Ouest Africaine; UEMOA) adopted a resolution that commits its member states to adopt the LMD system (UEMOA, 2007). The eight members of UEMOA are, in alphabetical order: Benin, Burkina Faso, Ivory Coast, Guinea Bissau, Mali, Niger, Senegal, and Togo.

The implementation of these initiatives is not coordinated. Indeed, although all of the UEMOA member countries belong to CAMES, the resolution on the LMD reform in the UEMOA countries does not refer to the same resolution adopted by all the CAMES member states. It also does not recognise the responsibility assigned to the CAMES academic bodies. We agree that CAMES should also have been assigned the role of overseeing the implementation of the decisions and resolutions of all these LMD reforms. Such a step would have helped to ensure synergies and facilitate the exchange of good practices between the three initiatives.

Currently, the implementation of the LMD reforms faces major challenges mainly due to: (a) the uneven involvement of the stakeholders in the reform processes, in particular students and administrative staff in universities, (b) the lack of quality assurance mechanisms, (c) the absence of the tools required to promote transparency and fairness in assessing degrees and periods of studies, and (d) the lack of measures to ensure the comparability and compatibility of degrees. Essential tools include credit transfer and accumulation systems, information centres on the recognition of degrees and periods of studies, and diploma supplement, a document issued by a higher education institution to provide a description of the qualification in an easily understandable way, espe- 
cially for employers and institutions located outside the country where the qualification was issued. All of these tools are explicitly provided for in the resolution adopted by the UEMOA member states.

Generally, implementing the LMD reform takes place in an atmosphere of tension between students and university administrators, most likely because they do not have a common understanding of this reform. However, it is worth mentioning that the Ministry of Higher Education and Research of Senegal organised a national consultation in April 20I3 in which all of the stakeholders considered the future of higher education, including the LMD reform. Seventy-eight recommendations were adopted by consensus (CNAES, 20I3b).

In the area of research, since the launch of the LMD reform, the Cheikh Anta Diop University of Dakar (Université Cheikh Anta Diop; UCAD) has established seven doctoral schools organised to provide the LMD sequence of degrees. Other universities in the CAMES member countries are at various stages in the creation of such schools. These doctoral schools are now promoting the internationalisation of higher education in Africa by admitting students from other countries in the region. For example, the UCAD's doctoral school of mathematics and computer science closely collaborates with the African Institute for Mathematical Sciences (AIMS-Senegal) in supervising PhD students. AIMS-Senegal was established in $201 \mathrm{II}$ in Mbour, Senegal, to provide $\mathrm{PhD}$ training programmes in mathematics in Africa and beyond. As of 20I3, AIMS-Senegal had already admitted 48 students from 20 African countries (AIMS, 2013).

2. The Programme on Mutual Recognition of Higher Education Degrees. A convention on mutual recognition of higher education degrees in the CAMES member states was signed in 1972 in Lomé, Togo. The ratification of this convention led to the establishment of a programme on mutual recognition of higher education qualifications (CAMES, 2007a).

As originally established, the evaluation of applications for recognition of degrees was conducted every two years by experts from CAMES member states and partner organizations through regional workshops. Since 2009, these workshops have been held annually. By September 2013 , this programme had organised 27 workshops and recognised 9I8 degrees out of I,242 applications, constituting a success rate of 73.9I\% (CAMES, 20I3a). Evaluations for recognition of periods of studies are not part of this programme. Thus, universities receiving applications for recognition of studies independently decide whether to recognise the periods of studies completed by the applicants.

In 2006, a resolution of the CAMES Council of Ministers has assigned to this programme the responsibility for accreditation and quality assurance in the CAMES member states. However, in 2007, the Council adopted a new framework for the recognition of degrees that takes the LMD reform into account (CAMES, 2007b). This framework was revised in 2012 and again 2013 (CAMES, 2013b). We agree that the current CAMES Special Colloquium document on the recognition of foreign qualifications, adopted in 1993 in Niamey, Niger (CAMES, I993) must be revised to accommodate the LMD system.

3. The Programme on Capacity Building in Quality Assurance. Since 2007, in collaboration with the Association of African Universities and the Francophone Universities Agency, CAMES implements a series of annual workshops aimed at building the capacity of higher education stakeholders in quality assurance. By September 2013, the programme had trained 246 member participants on issues related to quality assurance, including quality assurance procedures, the evaluation of higher education and research institutions, the implementation of the new framework for the recognition of degrees, and the quality assurance of private higher education institutions.

The main actors trained include rectors of universities, directorsgeneral of higher education institutions and services, academic staff, researchers, and administrative staff involved in the management of quality assurance.

The Inter-University Council for East Africa (IUCEA)

Following the collapse in I977 of the former East African Community that had established the Inter-University Committee in 1970 in Kampala, Uganda, for the purpose of promoting university cooperation, Vice-Chancellors of the Universities of Nairobi in Kenya, Dar es Salaam in Tanzania, and Makerere University in Uganda met in I980 in Nairobi, Kenya, to discuss future cooperation prospects between their respective institutions. Subsequently, they signed a memorandum of understanding that led to the establishment of the Inter-University Council of East Africa with headquarters in Kampala. This memorandum spells out IUCEA's objectives, functions, institutional set-up, systems of governance, and management. The IUCEA implemented its activities satisfactorily until 1992 when its financial resources had declined significantly, making it impossible to carry out collaborative activities. Six years later in I998, IUCEA commissioned a study undertaken by the Commonwealth Higher Education Management Services (CHEMS) with a view to developing a viable strategy for expansion and sustainability of IUCEA.The report of this study was completed in March I999 (IUCEA, 20I4). Following the recommendations of the CHEMS report, the Governments of Kenya, Tanzania and Uganda 
decided to undertake activities aimed at revitalizing the IUCEA. In September 2002, the ministers responsible for higher education of these three countries signed a Protocol replacing the I980 memorandum and making the IUCEA a legal body of the new East African Community, which had been reestablished in 2000 .

In 2009 the East African Legislative Assembly enacted the IUCEA Act-2009 to integrate IUCEA into the East African Community (EAC) operational framework.The IUCEA has the responsibility for ensuring internationally comparable standards in the five partner states of the East African Community: Burundi, Kenya, Rwanda, Tanzania, and Uganda. In 20I3, IUCEA had 96 member institutions including public and private universities, university colleges, and other degree-awarding institutions. Since 2005, the IUECA had developed a regional quality assurance system which initially involved Kenya, Tanzania, and Uganda. The initiative was extended to Burundi and Rwanda in 2008, after the two countries had joined the East African Community in 2007 .

The process of developing this system went through the following steps:

- Information visit of quality assurance stakeholders from the EAC Partner States to Europe to learn about issues of quality assurance from the experience of Germany and the Netherlands

- Organisation of national and regional dialogue forums

- Development of a quality assurance handbook, A Road Map to Quality: Handbook for Quality Assurance in Higher Education, in cooperation with the German Academic Exchange Service (DAAD) and the German Conference of Rectors

- Capacity building in quality assurance in universities, quality assurance agencies, and at the national level using that handbook

The handbook is the chief implement for developing a regional quality assurance system. It instructs quality assurance trainers and reviewers who are now instrumental in strengthening the capacity of quality assurance units in member institutions. By 2013 , hundreds of university staff had been trained in 70 pilot universities on issues of quality assurance and the use of the handbook, thus preparing them to serve as experts in coordinating quality assurance activities in their respective universities. In addition, 80 peers have been trained to participate in peer review exercises with a focus on developing quality improvement plans by the universities that had been reviewed.

The handbook is applied through pilot programme evaluation under the guidance and technical coordination of IUECA and national quality assurance agencies (Nkunya \& Cosam, 20I2; Shabani, 20I3). The hand- book is divided into four independent but complementary volumes: Volume I: Guidelines for Self-Assessment at Programme Level; Volume 2: Guidelines for Self-Assessment for External Assessment at Programme Level; Volume 3: Guidelines for Self-Assessment at Institutional Level; and Volume 4: Implementation of a Quality Assurance System.

Capacity-building training workshops on quality assurance issues and the use of the handbook are held periodically, both at national and regional levels under the coordination of national quality assurance agencies and the IUCEA respectively. The training needs are identified at the national level by member institutions and at the regional level by IUCEA through the regional capacity-building programme. At the regional level, trainings are conducted through annual East African Higher Education Quality Assurance Network Forums and training workshops that are structured through a specific period of time. As an example, the training on basic quality assurance runs through a period of 18 months comprising three fulltime workshops of 7 to io days. During that period, trainees continue to undertake various assignments at their home institutions related to self-assessment at the programme level.

An external evaluation of the initiative conducted in 2010 by a team of three international experts drawn from Africa, Europe, and Latin America showed that the initiative has achieved four significant results:

- Raising the awareness of the major quality assurance stakeholders

- Training quality assurance trainers and reviewers

- Establishment of quality assurance units in universities

- Acceptance of the principle of regular curriculum reviews (Lemaitre, Matos, \& Teichler, 20II)

The evaluation also recommended enhancing the participation of higher education and quality assurance stakeholders in the various quality assurance processes by incorporating stakeholders' perspectives-for example, in the definition of the minimum standards and the identification of learning outcomes.

Currently, all the stakeholders agree that the regional quality assurance system in the East African Community as established is operational. The IUCEA is committed to improving its performance and enhancing its effectiveness.

Since the signing of the East African Common Market Protocol in 2009, IUCEA has the responsibility of implementing the higher education provisions of this protocol's Article II, in particular the mutual recognition of qualifications and harmonisation of curricula (East African Community, 2009). The process of developing a regional harmonisation mechanism began in 2010 with the original goal of being 
completed by 20I5. It requires at least the establishment of a regional qualifications framework and a credit transfer and accumulation system, projected respectively for 2014 and 2015 (Nkunya, 20I4).

In addition to the delay already experienced, several other factors indicate that the expected results for the harmonisation mechanism will not be achieved within the planned deadlines. According to Nkunya (20I3), these include: (a) some countries' resistance to change, (b) disparities in existing curricula, (c) variations in the quality of teaching and learning, (d) budget cuts, and (e) delays in countries' payment of their financial contributions to IUCEA.

\section{At the Continental Level}

We discuss four organisations that are involved in the design and implementation of quality assurance initiatives. They are the United Nations Educational, Scientific and Cultural Organisation; the Association of African Universities; the African Union Commission, and the Association for the Development of Education in Africa.

\section{The United Nations Educational, Scientific and Cultural Organization (UNESCO)}

UNESCO provides technical and financial support to organisations involved in quality assurance enhancement in Africa, including the African Union Commission, the Association of African Universities, the African Quality Assurance Network, and CAMES. It also directly implements capacity-building activities in quality assurance and teaching and learning in higher education through its cluster offices in Harare, Zimbabwe, and Bamako, Mali.

Since 2006 , UNESCO and its partners have organised five international conferences, originally designed as annual events. The first three were held annually (Nairobi, 2006; Dar es Salaam, 2007; and Dakar, 2008), followed at two-year intervals for the fourth and fifth (Bamako, 20Io; and Abidjan 20I2). The sixth conference is scheduled for September 20I4 in Accra. These conferences on quality assurance in higher education in Africa have helped to train more than 700 experts in such key issues as: (a) accreditation at the programme and institutional levels; (b) quality assurance of teaching, learning, and research; (c) conducting institutional audits and visitation; and (d) the use of ICT in quality assurance practices. UNESCO has recently developed its Guide on Quality Assurance in Higher Education in Africa, which focuses on the training of trainers in quality assurance in higher education (Shabani \& Okebukola, 20I4). This guide is different from the IUCEA quality assurance handbook, developed in cooperation with the German Academic Exchange Service (DAAD) and the German Conference of Rectors.

These UNESCO-sponsored conferences have played a positive role in human capacity building, fostering awareness of major actors, the emergence of several agencies, and the promotion of regional cooperation in quality assurance (Shabani, 20I3). In addition, two UNESCO world conferences on higher education a decade apart, I998 and 2009, underscored the importance of pedagogic training for higher education teachers. A few years before the I99 8 World Conference on Higher education, the UNESCO Regional Bureau for Education in Africa (BREDA) produced The Guide to Teaching and Learning in Higher Education as a resource for improving the quality of teaching and learning in higher education in Africa (Obanya, Shabani, \& Okebukola, I998).

Since the Guide's publication in I998 and online implementation through the Virtual Institute for Higher Education Pedagogy (VIHEP) in 2002 and the Virtual Institute for Higher Education in Africa (VIHEAF) in 2005, it has been used by more than Io,000 higher education teachers in Africa. Feedback from participants has confirmed the Guide's positive impact on improving the quality of teaching and learning. However, participants underscored the need for periodic updates in response to emerging developments in higher education in Africa. As a result, the UNESCO Bamako Cluster Office in 2013 published a new Guide to Effective Teaching and Learning in Higher Education (Shabani \& Okebukola, 2013). It covers I9 modules that respond to the contemporary developments of higher education in Africa. Selected examples are:

- Understanding the higher education learner

- Curriculum development in higher education

- Effective teaching of first-year students

- Teaching and learning in agriculture, the arts, sciences, and medical sciences

- New technologies in teaching and learning

- Delivering higher education using distance education methodologies

- Empowering women for success in higher education

- Empowering students with special needs

This Guide will be used to train higher education teachers in Africa online through the Virtual Institute for Improving Quality of Higher Education in Africa (Shabani, 20I4)

The Association of African Universities (AAU)

The Association of African Universities implements two initiatives: the African Quality Assurance Network and the Europe-Africa Quality Connect. 
1. The African Quality Assurance Network (AfriQAN) was established by the Association of African Universities in 2007 to promote collaboration among existing quality assurance agencies. Its main activities are capacity building of these agencies and the implementation of the African Quality Assurance Peer Review Mechanism (AQAPRM).

AfriQAN organised several capacity-building training workshops for national quality assurance agencies in Africa with the support of the Global Initiative for Quality Assurance Capacity (GIGAC), an initiative of the World Bank implemented under the coordination of UNESCO. Some of these workshops were organized in collaboration with the International Network for Quality Assurance Agencies in Higher Education (INQAAHE). In addition to AfriQAN and INQAAHE, implementation of GIGAC involved five other regional quality assurance networks covering Arab countries, Asia and Pacific, Caribbean countries, Europe, and Latin America.

AfriQAN set up the African Quality Assurance Peer Review Mechanism to assess, on a voluntary basis, the performance of a quality assurance agency by another agency, on the basis of established criteria. The first peer review mission was organised in December 20II at the Tertiary Education Commission (TEC) in Mauritius. Recommendations made for improving TEC's operations are currently being implemented. However, the sustainability of this programme depends on AfriQAN's ability to mobilise new financial resources (Okebukola, 20IIb; Shabani, 20I3).

2. The Europe-Africa Quality Connect Pilot Project, co-funded by the Erasmus Mundus programme and the European Union Commission, was established in October 2010 with the goal of strengthening institutional development and quality assurance in five Sub-Saharan African institutions: the University of Namibia; Kenyatta University, Kenya; Omar Bongo University, Gabon; Institute of Professional Studies, Ghana; and Ahmadu Bello University, Nigeria. The Association of African Universities implemented this project in 20I0-20I2 in collaboration with the European Universities Association, the University of Aveiro in Portugal, and the Irish University Quality Board.

The pilot project implemented the Institutional Evaluation Programme (IEP, 20IO) including the following activities: (a) institutional evaluations in five universities participating in the project; (b) training workshops for experts of the evaluation teams; (c) workshops on selfevaluation, and (d) a final dissemination conference. The project was successfully completed in September 2012 with the following two major outcomes: It confirmed the need to conduct institutional evaluations in Africa, and it showed that the Institutional Evaluation Programme is applicable to different African higher education contexts. At the final dissemination conference held in June 2012 in Addis Ababa, Ethiopia the AAU made a commitment to mobilise resources that will allow applying this project to other institutions.

The African Union Commission (AUC)

The African Union Commission currently implements three initiatives: (a) the Higher Education Harmonisation Strategy, (b) the Tuning Africa Project, and (c) the African quality assurance rating mechanism. The AUC also supports the Association for the Development of Education in Africa in its efforts to establish an African higher education and research space in accordance with a recommendation of the 2009 World Conference on Higher Education.

1. The African Higher Education Harmonisation Strategy was adopted in 2007 to achieve the following five core results by 2015 (African Union, 2007a):

- Establishment and maintenance of the continental political commitment to the process of harmonisation

- Cooperation in an information exchange

- Development and maintenance of a continental framework for higher education qualifications

- Creation of minimum standards in targeted qualifications

- Establishment of joint curriculum development and student mobility schemes

We agree that achieving these results, especially in combination, will improve the comparability and compatibility of higher education programmes and qualifications. The harmonisation strategy will therefore facilitate the mutual recognition of qualifications; promote academic mobility on the continent, and contribute towards the establishment of an African higher education and research space.

Unfortunately, recent reports on the implementation of the harmonisation strategy work plan show that it is currently lagging in some tasks and will not achieve some of the results expected at the end of its implementation date in 2015 (Oyewole, 20II, 20I3; Shabani, 20I3). These include the establishment of a continental qualifications framework, the development of a continental credit transfer and accumulation system, and the creation of a central database on the recognition of qualifications. These three tools are required to ensure the effective implementation of the joint curricula, student mobility schemes, and the revised Arusha Convention.

The Regional Convention on the Recognition of Studies, Certificates, Diplomas, Degrees, and other Academic Qualifications in Higher 
Education in the African States, also known as the Arusha Convention was adopted by the African Ministers of Education in December I98I in Arusha, Tanzania, to promote academic mobility. The implementation of the convention was weak, partly because, by 2002 , it had been ratified by only 22 member nations. In 2002 UNESCO and the Commonwealth of Learning collaborated on revising the convention, a process motivated by the major challenges facing higher education in Africa in the early 2000 s, including a rapid increase in student enrolments, the deterioration of the quality of education, and the lack of relevance and equity in the higher education systems. As the African Union recognised, it was necessary to adapt appropriately such existing legal instruments as the Arusha Convention to ensure that they confront and help resolve these serious challenges (AU, 20II). Since 2007 , the revision continued jointly by UNESCO and the African Union Commission; it was competed in 2013 . The slow progress made in both the revision of the convention and implementation of the strategy could indicate that the mechanisms for overseeing these processes were ineffective.

Indeed, although the Arusha Convention and the harmonisation strategy focus primarily on the quality of academic programmes and institutions, their implementation does not adequately involve stakeholders in higher education and quality assurance. The delay in implementing the revision of the convention and the harmonisation strategy must be at least partly attributed to the member countries' reluctance to undertake the measures necessary to expedite these processes. It also seems inevitable that implementation of the revised Arusha Convention will face some challenges due to the lack of tools needed to ensure transparent and fair assessment of qualifications and periods of the studies.

2. The Tuning Africa Pilot Project is a collaborative, highly consultative process that involves major higher education stakeholders from specific subject areas in curriculum development to enhance student competences. It focuses on required generic and subject-specific competences, credit transfer and accumulation systems, teaching and learning approaches, and assessment and quality enhancement. Those involved in the Tuning Africa pilot project anticipated that it would promote implementation of the Harmonisation strategy. It was launched in 20II with funding from the European Union Commission for a period of I8 months to focus on the identification of generic and subject-specific competences. The intended learning outcomes and skills are clustered in the following five subjects areas: agriculture, civil engineering, mechanical engineering, medicine, and teacher education.
This exercise involved 57 universities in all five of the African regions and all the major stakeholders at national, institutional, and community levels including professional associations, the private sector, students, future employers, and beneficiaries of the higher education services. The skills and competences identified through Tuning for each subject area had, as a goal, comparability with and the ability to meet the needs and priorities of the labour market. The Tuning project as it unfolds will facilitate the harmonisation of programmes at the level of subject areas. It will therefore contribute to the establishment of a continental credit transfer and accumulation system and, consequently, to the promotion of students' mobility.

The Tuning Africa project has been integrated in the new Erasmus+ Programme adopted by the European Union for 20I4-2020 (European Union, 2013). A detailed analysis on the experience of the Tuning Africa pilot project has been recently published by Hahn and Teferra (2013) with subject-specific analyses appearing in Onana, Oyewole, Teferra, Beneitone, González, and Wagenaar (20I4).

3. The African Quality Rating Mechanism (AQRM) was established in 2007 by the African Union (AU, 2007b) to encourage higher education institutions to voluntarily assess their performance against a set of criteria established in the quality rating mechanism survey questionnaire (AU, 2009). These criteria are largely consistent with the standards for institutional quality assurance used in Nigeria and South Africa (Shabani, 20I3). The AQRM differs, however, from ranking systems. It helps to put African higher education institutions in clusters according to prescribed quality standards required for participation in continental academic mobility programmes such as the Mwalimu Nyerere scholarship scheme launched in 2007 to contribute to training and retention of high-level human resources in key areas of sustainable development. AQRM will also be used to select institutions that will be considered for membership in the Pan African University networks of centres of excellence.

In 20I0, 32 higher education institutions from II countries participated in the pilot project, undertaken on the basis of self-assessment. A project report produced by the African Union Commission noted some shortcomings including lack of external validation of the selfassessment results and difficulty in drawing relevant conclusions from the information collected since some institutions failed to complete the entire survey (AU, 20I2; Mohamedbhai, 20I2c; Shabani, 20I3).

The African Union Commission report recognises the need to revisit the survey and to conduct another pilot phase prior to scaling up the mechanism to all the institutions. Based on the lessons learned from 
the first pilot phase, the African Union Commission revised its survey questionnaire in August 2013 in collaboration with the Association of African Universities and invited higher education institutions to participate in a new pilot phase that is currently being implemented in 20I4. Hopes are high in Africa and the rest of the world that AQRM will evolve into a respectable international rating scheme.

\section{The Association for the Development of Education in Africa (ADEA)}

The UNESCO-sponsored 2009 World Conference on Higher Education recommended that Africa establish a continental quality assurance mechanism to catalyse the development of an African higher education space. As a follow-up to this recommendation, the ADEA Working Group on Higher Education convened a brainstorming session of experts in December 20I0 in Accra, Ghana, to discuss modalities for establishing such a space. The meeting adopted a concept note (ADEA, 2OII) and initiated the development of a set of analytical studies to document the process of construction of an African Higher Education and Research Space (AHERS) The next step is to submit the project document to the Conference of African Ministers of Education for approval.

Meanwhile, the African Union Commission has launched the process of establishing an African Accreditation Framework. This initiative together with the proposed project of establishing an African quality assurance framework and the Tuning Africa project will provide a strong foundation for developing the African Regional Qualifications Framework and a comparable credit transfer, thereby contributing to the construction of the AHERS.

\section{The Challenges}

The improvement of quality of higher education in Africa and the strengthening of quality assurance regimes confront at least three challenges: (a) weaknesses in implementing the higher education harmonisation strategy, (b) inadequate human capacity, and (c) institutional lethargy.

Weaknesses in Implementing the Higher Education Harmonisation Strategy In the last I5 years, the Regional Conventions on the Recognition of Studies, Certificates, Diplomas, Degrees and Other Academic Qualifications in Higher Education in the States belonging to the Europe, Africa and the Asia-Pacific regions, adopted I979, I98I, and I983 respectively, have undergone revisions for the purpose of improving transparency and efficiency in recognition procedures, of making qualifications more easily understandable, and for enhancing academic mobility.
These revised conventions were expected to serve as building blocks for constructing higher education areas. The revised European Convention now called the Convention on the Recognition of Qualifications concerning Higher Education in the European Region (popularly known as the Lisbon Convention) adopted in Lisbon on April II, I997, facilitated the creation and refinement of several tools that allowed improved comparability of qualifications. These tools include: (a) the European Network of Information Centres on Academic Recognition and Mobility, (b) the European Association for Quality Assurance in Higher Education, (c) the European Quality Assurance Register for Higher Education, (d) the European Credit Transfer and Accumulation System, and (e) the Diploma Supplement, which a higher education institution issues to provide an easy-to-understand description of the qualification, especially for non-national employers and institutions. The implementation of the Bologna Process, which began in 1999, has relied emphatically on the use of these tools and mechanisms.

The situation in Africa is different. Indeed, the revised Arusha Convention which was expected to support the implementation of the harmonisation strategy was completed only in 2013 . The harmonisation strategy includes activities related to the finalisation of the revised Arusha Convention, preparations for its signature and ratification, and the development of tools required to ensure the mutual recognition of degrees and periods of studies among member nations. However, its implementation is lagging, including aspects related to the Arusha Convention. Furthermore, although the harmonisation strategy was planned to build on existing initiatives at national and regional levels, no mechanism has been set up to ensure a cooperative relationship between harmonisation and these initiatives. Finally, the strategy's implementation does not adequately involve stakeholders in higher education and quality assurance, thus raising the prickly challenges of ownership, inclusiveness, and leadership as pointed out by Teferra (2012).

\section{Inadequate Capacity Building}

Today, quality assurance is at the heart of all efforts to revitalise higher education in Africa. These efforts have led to a rapid increase in the number of quality assurance agencies. However, at least $60 \%$ of the agencies lack the human and institutional capacity needed to implement their mandates effectively (Shabani, 2013). Strengthening these capacities is urgent, as is the demand that it be done in the present moment, especially given the awareness of several African countries of 
the need for new institutions that can respond adequately to growing demands in their own nations for greater access to higher education.

\section{Institutional Lethargy}

Many of the higher education institutions in Africa still delay in developing quality assurance at both the national and continental levels. Few practitioners at the institutional level are aware of the Arusha Convention, either in its original or its revised form, or of the AHERS programme. Policymakers and leaders of higher education institutions still need to be encouraged to show commitment to the revitalisation process. Quality assurance must start at the local institutional levels, and members of university governing councils and other leadership positions must not be those who see universities as money-making sources or as methods of pursuing other political or personal interests. Universities in Africa should become aware that quality starts with their commitment to their institution's vision, mission, and values and that such a commitment must not be made to serve other political and social ends.

\section{Concluding Remarks and the Way Forward}

This article reviewed the major initiatives taken at the national, regional, and continental levels to improve the quality of higher education in Africa. These initiatives include: (a) the creation or strengthening of quality assurance mechanisms; (b) critical revisions of conventions on mutual recognition of degrees and periods of studies; (c) the harmonisation of programmes and qualifications, and (d) the construction of an African higher education and research space.

The review has identified a major opportunity for regional quality assurance stakeholders. Indeed, as discussed in the section on the InterUniversity Council for East Africa, that body has been quite successful in establishing a regional quality assurance system in the East African Community. Higher education proponents urge that other regional communities consider developing similar models, which will improve the quality of higher education in their respective regions. Actually, the successful implementation of the system in East Africa led the German Academic Exchange Service (DAAD) to initiate a similar system in West and Central Africa in 2013 in collaboration with the African and Malagasy Council for Higher Education and UNESCO (DAAD/UNESCO, 2OI2).

In the light of the challenges identified, we recommend the following actions to the stakeholders at national, regional, and continental levels:

- Allow the participation of all the stakeholders in the various ongoing reform processes to make them more effective
- Strengthen the capacity of stakeholders in the areas of quality assurance

- Improve institutional capacity in teaching and learning in higher education, using, for example, the 2013 Guide to Effective Teaching and Learning in Higher Education developed by UNESCO

- Build capacity for the rapid development of tools required to facilitate the mutual recognition of degrees and periods of studies, to improve the comparability of programmes, to provide better matches among qualifications in various higher education programmes, and to promote mobility. These steps will facilitate the more rapid realisation of the African Higher Education and Research Space (AHERS) and establish a stronger foundation for future developments.

\section{References}

ADEA. Association for the Development of Education in Africa. (2OII). Creating an African higher education and research space: A concept note. Tunis: ADEA. Retrieved on January 8, 20I4, from https:// www.google.fr/?gfe_rd=cr\&ei=u2RaU9T9AsLX8gfG 5 YBw\#q=AD $\mathrm{EA}+$ Creating+an+African+higher+education+and+research+spac $\mathrm{e} \% 3 \mathrm{~A}+\mathrm{A}+$ concept+note.

African and Malagasy Council for Higher Education. See CAMES.

AIMS. The African Institute for Mathematical Sciences (AIMS-Senegal). (20I3). Retrieved on February 22, 20I4, from http://www. aims-senegal.sn/.

AU. African Union (2007a). Harmonisation of higher education programmes in Africa: A strategy for the African Union. Third Ordinary Session of the Conference of Ministers of Education of the African Union (COMEDAF III), August 6-IO, 2007, Johannesburg, South Africa.

AU. African Union. (2007b). Developing an African higher education quality rating system. Meeting of the Bureau of the Conference of Ministers of Education of the African Union (COMEDAF II+), May 29-3I, 2007, Addis-Ababa.

AU. African Union, (2009). Developing a quality rating mechanism for African higher education. Survey questionnaire. Addis Ababa, 2009.

AU. African Union. (May 20II). Regional convention on the recognition of studies, certificates, diplomas, degrees, and other academic qualifications in higher education in African states. First extraordinary session of the Conference of Ministers of Education of the African Union (COMEDAF IV+), Nairobi, Kenya, May II-I3, $20 I I$.

AU. African Union. (2012, April). African quality rating mechanism: 2010 
pilot self rating of higher education institutions: Summarised report. Addis Ababa: AU.

CAMES. African and Malagasy Council for Higher Education. (I993, September 20-25). Colloque spécial du CAMES sur la reconnaissance et l'équivalence des diplômes étrangers. Conference held at Niamey, Niger. Retrieved on February II, 20I4, from http://www.lecames. org/IMG/pdf/diplomes_colloque_special_niamey_20_25_I993. pdf.

CAMES. African and Malagasy Council for Higher Education. (2006). Résolution no. 4 sur le passage au LMD. Retrieved on February Io, 20I4, from http://www.lecames.org/IMG/pdf/Resolutiono406CAMES.pdf.

CAMES. African and Malagasy Council for Higher Education. (2007a). Programmes: Reconnaissance et équivalence des diplômes. Présentation du programme. Retrieved on January 30, 20I4, from http:// www.lecames.org/IMG/article_PDF/article_6.pdf.

CAMES. African and Malagasy Council for Higher Education. (2007b.) Proposition de référentiel au format LMD: Equivalence et reconnaissance du CAMES. Retrieved on February I, 20I4, from http://www. lecames.org/diplome_cames/files/référentiel_LMD-2.pdf.

CAMES. African and Malagasy Council for Higher Education. (2013a, September). Le CAMES: Un outil de construction de l'excellence dans l'enseignement supérieur, la recherche scientifique et l'innovation. (in press).

CAMES. African and Malagasy Council for Higher Education. (2013b). Répertoire sur la reconnaissance et l'équivalence et l'assurance qualité. http://www.lecames.org/diplome_cames/.

CEMAC. Communauté économique et monétaire de l'Afrique Centrale. Central African Economic and Monetary Community. (2005). Sixième session de la conférence des chefs d'états. Déclaration de Libreville sur la construction de l'espace CEMAC de l'enseignement supérieur, de la recherche et de la formation professionnelle. Retrieved on January I4, 20I4, from http://www.cemac.int/sites/default/ files/documents/files/declaration\%2ode\%2olbv\%2osur\%20 enseignement\%2osuperieur.pdf.

CNAES. (2OI3a). Concertation Nationale pour l'avenir de l'enseignement supérieur au Sénégal; National Dialogue for the Future of Higher Education in Senegal. L'enseignement supérieur en chiffres. Retrieved on January 25, 20I4, from http://www.cnaes.sn/index.php/sliders/ les-chiffres-de-l-ens-sup.

CNAES. (20I3b). Concertation Nationale pour l'avenir del'enseignement supérieur au Sénégal; National Dialogue for the Future of Higher
Education in Senegal. Concertation nationale pour l'avenir de l'enseignement supérieur au Sénégal. Rapport général. Retrieved on January 25, 20I4, from http://www.cnaes.sn/.

DAAD/UNESCO. (20I2). Deutscher Akademischer Austauschdienst (German Academic Exchange Service) (20I2). Conference on strengthening regional cooperation in quality assurance in Central and West African universities, in Dakar, Senegal, November 15-17, 2012. Retrieved on January I6, 20I4, from http://www. unescoafrica.org/ highered/.).

Daniel, J., \& Uvaliæ-Trumbic, S. (Eds.). (2013). A guide to quality in online learning. Retrieved on January I4, 20I4, from http://www. contactnorth.ca/tips-tools/guide-quality-online-learning.

EAC. East African Community. (2009). Protocol on the establishment of the East African Community Common Market: Intergovernmental agreement. Arusha: EAC, 2009. Retrieved on February II, 20I4, from http:// www.commonmarket.eac.int/documentation/doc_ view/48-common-market-protocol.raw?tmpl=component.

European Ministers of Higher Education. (200I, May 19). Towards the European higher education area: Communiqué of the meeting of European Ministers in charge of Higher Education in Prague. Retrieved on January 30, 20I4, from http://www.ond.vlaanderen.be/hogeronderwijs/bologna/documents/MDC/PRAGUE_COMMUNIQUE.pdf.

European Ministers of Higher Education, (2013, September 19). Realising the European higher education area: Communiqué of the conference of ministers responsible for higher education. Retrieved on January I3, 20I4, from http://www.ond.vlaanderen.be/hogeronderwijs/ bologna/documents/MDC/Berlin_Communiquer.pdf.

European Union. (2013). Erasmus+: Worldwide opportunities for higher education cooperation, 2013. Retrieved on January 2, 20I4, from http://www.oead.at/fileadmin/icm/eu_dritt/20I3/Erasmus__ international_leaflet.pdf.

IEP. Institutional Evaluation Programme. (20I0). 10 year anniversary. Institutional evaluation programme. European Universities Association, Brussels, 2004. Retrieved on February 20, 20I4, from http://www.eua.be/eua/jsp/en/upload/IEP_anniversary_brochure.Io86687063630.pdf.

IUCEA. Inter University Council of East Africa. (1980). Overview of the IUCEA. Retrieved on January 30, 20I4, from http://www.iucea. org.

Hahn, K., \& Teferra, D. (20I3). Tuning as an instrument of systematic higher education reform and quality enhancement: The African experience. Tuning Journal for Higher Education Issue No. I, I27-I63. 
Retrieved on February 28, 20I4, from http://www.tuningjournal. org/public/site/or/oI_TuningJournal_NewProfilesForNewSocieties.pdf.

Lemaitre, M. J., Matos, N., \& Teichler, U. (20II, March). East African-German cooperation in enhancing quality assurance in higher education: An external review of the IUCEA-DAAD pilot initiative. IUCEA, Kampala, 20II. Retrieved on January 8, 20I4 from http:// iucear.org/qawp/wp-content/uploads/2013/I2/REVIEW-IUCEADAAD-QA-INITIATIVE-MARCH-2OII.pdf.

Marope, P.T.M., Wells, P. J., \& Hazelkorn, E. (Eds.). (20I3). Rankings and accountability in higher education uses and misuses. United Nations Educational, Scientific, and Cultural Organisation. Retrieved on January 8, 20I4, from http://www.unesco.org/new/typoztemp/ pics $/ 69$ b7i4f58c.jpg.

Materu, P. (2007). Higher education quality assurance in Sub-Saharan Africa: Status, challenges, opportunities, and promising practices. Washington, DC.: World Bank. Retrieved on January I3, 20I4, from http://www.eua.be/Libraries/QA_Connect/wpi24_qa_higher_ edu_africa.sflb.ashx.

Mohamedbhai, G. (20I2a). Global rankings of universities: Where do African universities stand? Paper presented at PULSAR Residential Workshop, Johannesburg, South Africa, November 5-9, 20I2. Retrieved on February 2, 20I4, from http://www.sarua. org/files/PULSAR/Presentations/3-Prof\%20Mohamedbhai\%20 Global\%2oRankings.pdf.

Mohamedbhai, G. (20I2b, March II). Are national goals for doctoral education realistic? University World News, Issue No. 212. Retrieved on January I8, 20I4, from http://www.universityworldnews.com/ article.php?story $=2012030615004517 \mathrm{I}$.

Mohamedbhai, G. (20I2c). African quality rating mechanism: Pilot results and challenges in future implementation. Paper presented at PULSAR Residential Workshop, Johannesburg, South Africa, November 5-9, 20I2. Retrieved on January I8, 20I4, from http://www.universityworldnews.com/article.php? story=20120928I70840II9.

Nkunya, M.H.H. (2013, September I4). East Africa higher education boss warns of more harmonisation delays. University World News, Issue No. 287. Retrieved on January 8, 20I4, from http://www.universityworldnews.com/article.php?story=201309I3II5I49427.

Nkunya, M.H.H. (20I4, January I7). Why higher education harmonisation is taking so long. University World News, Issue No. 303. Retrieved on February 8, 20I4, from http://www.universityworldnews.com/article.php?story=20I40II7I45931648.
Nkunya, M.H.H., \& Cosam, J. C. (20I2). Developing a regional quality assurance system for higher education in East Africa: Progress and experiences. Kampala, Uganda: Inter University Council for East Africa.

Obanya, P., Shabani, J., \& Okebukola, P. (1998). A guide to teaching and learning in higher education. Dakar: UNESCO Regional Bureau for Education in Africa (BREDA).

Okebukola, P. A. (20IIa.) Nigerian universities and world ranking: Issues, strategies, and forward planning. Paper presented at the $201 \mathrm{II}$ Conference of Association of Vice-Chancellors of Nigerian Universities, held at Covenant University, Ota, June 27-30, 20II. Retrieved on February 3, 20I4, from http://www.google.com/url?sa=t\&rct=j\&q $=\&$ esrc $=$ s\&source $=$ web\&cd $=2 \&$ cad $=$ rja\&ved $=0 C D E Q F j A B \& u r l=h$ ttp\%3A\%2 F\%2 Fxa.yimg.com\%2 Fkq\%2Fgroups\%2Fig 6748\%2FI $394473132 \% 2$ Fname\%2FOkebukola-University-Ranking-20II.pdf and \&ei=_a34UpLOCsSboQXRioH4AQ\&usg=AFQjCNFA4H6Ks BpQorRqNGH3rowmiDv4ZA\&bvm=bv.60983673,d.bGQ.

Okebukola, P. A. (20IIb). Peer review of quality assurance in Africa. Retrieved on February 3, 20I4, from http://www.academia.edu/5166995/ Peer_Review_Of_Quality_Assurance_Agencies_In_Africa.

Okebukola, P. A. (2013, September 24-25). Legislative framework for enhancing minimum standards in Nigeria's federal education system. Paper presented at the Conference of the Nigeria Legislature on Education Organised by the Senate Committee on Education on the theme of "Transforming Nigeria's Education Sector: The Legislative Agenda." Abuja, Nigeria: National Universities Commission.

Okebukola, P. A. (20I4, January 29-30). Emerging regional developments and forecast for quality in higher education in Africa. Paper presented at the 20I4 International Quality Group Annual Conference organised by the Council on Higher Education in Africa. Washington, DC: CHEA.

Okebukola, P., \& Shabani, J. (2007). Quality assurance and accreditation in higher education in Sub-Saharan Africa. In Global University Network for Innovation (GUNI) (Ed.), Higher education in the world 2007: Accreditation for quality assurance - what is at stake? (pp 46-59). New York: Palgrave Macmillan.

Okebukola, P. A., \& Shabani, J. (20I2). Report of the study on the establishment of the Africa regional quality assurance framework. Study commissioned by the ADEA (Association for the Development of Education in Africa) Working Group on Higher Education, Tunis, 2012.

Onana, C. A., \& Oyewole, O., Teferra, D., Beneitone, P., González, J., 
\& Wagenaar, R. (Eds.). (20I4). Tuning and harmonisation of higher education: The African experience. Bilbao, Spain: Deusto University.

Organisation for Economic Co-operation and Development. OECD. (2013). Education at a glance: OECD indicators. Retrieved on March 8, 20I4, from http://www.oecd.org/edu/eag2013\%20(eng)--FINAL $\% 2020 \% 20 J u n e \% 202013 . p d f$.

Oyewole, O. (20II). Harmonisation of degree structures and regional qualification frameworks in African higher education space. Paper presented at the Conference of Rectors, Vice-Chancellors, and Presidents (COREVIP) of African Universities. Stellenboch, South Africa: Association of African Universities.

Oyewole, O. (2013, January). African harmonisation: An academic process for a political end? Chronicle of African Higher Education, No. I. Retrieved on February I9, 20I4, from https://htmldbprod. bc.edu/prd/f?p=2290:4:0::NO:RP,4:Po_CONTENT_ID:II9500.

PDESR. (20I3, August). Plan national du développement de l'enseignement supérieur et de la recherche au Sénégal; National plan for the development of higher education and research in Senegal. Retrieved on January I6, 20I4, from http://www.gouv.sn/IMG/pdf/Plan _de_developpement_de_l_enseignement_superieur_et_de_la_ recherche_PDESR.pdf.

Sangala, C. (20I4, April). Private communication. Ministère de l'Enseignement Supérieur et de la Recherche Scientifique du Mali, Bamako, 20I4.

Shabani, J. (2013, May). Quality regimes in Africa: The reality and the aspirations. Chronicle of African Higher Education, No. 4. Retrieved on January 22, 20I4, http://www.bc.edu/content/bc/research/ cihe/inhea/chronicle.html.

Shabani, J. (2014, January 26). UNESCO virtual institute to help improve higher education quality. University World News, Issue No. 304. Retrieved on February 3, 20I4, from http://www.universityworldnews.com/article.php? story=20140I23180356367.

Shabani, J., \& Obebukola, P. A. (Eds). (20I3). Guide to effective teaching and learning in higher education in Africa. Bamako, Mali: UNESCO Bamako Office.

Shabani, J., \& Okebukola, P. A. (Eds.). (2014, in press). Guide on quality assurance in higher education in Africa. Bamako, Mali: UNESCO.

Spaull, N. (2013, October). South Africa's education crisis: The quality of education in South Africa 1994-2011. Report commissioned by the Centre for Development \& Enterprise. Retrieved on January 30, 20I4, from http://www.section27.org.za/wp-content/uploads/2013/10/ Spaull-20I3-CDE-report-South-Africas-Education-Crisis.pdf.
Teferra, D. (20I2, January 30). Harmonisation and tuning: Integrating the African higher education space. The World View. Retrieved on February I, 20I4, from http://www.insidehighered.com/blogs/ harmonisation-and-tuning-integrating-african-higher-educationspace.

UCAD. Université Cheikh Anta Diop de Dakar. (20I3, July 30). Université Cheikh Anta Diop de Dakar: Les chiffres qui font peur. EnquetePlus. Retrieved on February I8, 20I4, from http://www. seneweb.com/news/Education/universite-cheikh-anta-diop-dedakar-les-chiffres-qui-font-peur_n_IoI933.html.

UEMOA. (2007). Union Économique et Monétaire Ouest Africaine; West African Economic and Monetary Union. Directive No. 03/2007/CM/UEMOA portant adoption du système Licence, Master, Doctorat (LMD) dans les universités et établissements d'enseignement supérieur au sein de l'UEMOA. Retrieved on February 7, 20I4, from http://www.uemoa.int/Documents/Actes/Directive_03-2007-CMUEMOA_portant_adoption_LMD.pdf.

UNESCO Institute for Statistics. (2013). Global teacher shortage. Retrieved on February I7, 20I4, from http://www.uis.unesco.org/Education/ Pages/world-teachers-day-20I3.aspx.

University Act. (20I2a). The University Act No. 42 of 20I2. Kenya Gazette, Supplement No. I92. Retrieved on January 6, 2014, from http://www.uonbi.ac.ke/sites/default/files/The\%2oUniversities\%20Act\%202012_o.pdf.

Université de Bamako. (2008). Session annuelle du programme de formation de formateurs 2008. Retrieved on January II, 20I4, from http://u-bamako.ml.refer.org/?articlei83. 